However, if as Professor Holmes suggests, the granite be Caledonian and its cover were removed before the Carboniferous was deposited it would be difficult for our gravity data alone to distinguish the mode of origin of the granite.

\title{
(2) The Estimation of Mass Deficiency
}

The deficiency of mass was estimated by integrating the anomaly over a limited area. The total mass deficiency in a crustal column, relative to a neighbouring column, will be zero if $(a)$ the crustal structure were originally homogeneous; $(b)$ there were no change in density of the "granite", nor of the hypothetical stoped mass, during emplacement ; $(c)$ there were no possibility of outflow at depth ; $(d)$ there had been no subsequent doming. If the gravity anomalies from surrounding geological features were negligible, then integrating the anomaly to infinity over a plane surface will give a zero estimate. By finitely limiting the bounds of integration, we limit the depth to which the estimate applies. A near surface mass deficiency will give a sharp and well defined negative anomaly, while an equal surplus of mass at depth will give a broader and shallower positive anomaly. When vertically combined, the estimate obtained by summing the central negative anomaly alone will give an underestimate of the deficiency of mass. Therefore our conclusion does not depend on detecting the presence of stoped material at depth. The deficiency of mass in the upper crust under Weardale is certain, and our estimate may be low. That it is due to direct density contrast with a steep boundary in places follows from the Bouguer gradients. Such a mass deficiency could not be compensated by an equivalent mass surplus as a basic front immediately above and around.

A theoretical discussion of granites and their gravity anomalies is the subject of a paper already submitted to this journal, and field investigations of this problem are continuing.

THE SEDGwick MuSEum,

M. H. P. BotT.

D. Masson-Smith.

CAMBridge.

24th April, 1953.

REFERENCES

DunhaM, K. C., 1934. The genesis of the North Pennine ore deposits. Quart. Journ. Geol. Soc., xc, 689-720.

MinistrY OF FUEL AND POWER, 1945. Durham Coalfield Regional Survey Report. (Northern " A " region.) H.M. Stationery Office.

Northumberland and Cumberland Regional Survey Report. (Northern "B" region.) H.M. Stationery Office.

\section{LUDLOVIAN RESEARCH GROUP}

SIR,--Some of your readers may be interested to hear of the recent formation of a Ludlovian Research Group. The aim of the group is to encourage closer co-operation between geologists who are working on the problems of the Ludlovian rocks. An inaugural meeting was held at Birmingham University from the 24th to the 26th September, 1952, and fifteen geologists were present. Exhibits from various areas were studied and discussions took place on many topics, including the following:--Ludlovian correlation and classification, the Siluro-Devonian boundary, the Wenlock-Ludlow boundary, the sedimentary petrology and palaeontology of the Ludlovian, and the compilation of an annotated bibliography. A typescript bulletin will be published periodically for limited circulation amongst interested workers ; it is intended to contain information from members on mapping and research progress, interesting localities, museum collections, new techniques, recent literature, etc. The 1953 meeting of the group will take the form of a field excursion around the Welsh Borderland areas of Ludlovian 
rocks. The provisional dates are from the 9 th to the 16th September, 1953. Geologists interested in the Silurian rocks, and the Ludlovian rocks in particular, are invited to write to the undersigned for a fuller report on the 1952 conference, and for any other information.

\section{Department of Geology, \\ THE UNIVERSITY, EDGBASTON, BIRMINGHAM, 15. 27th April, 1953.}

J. D. LAwSON.

\section{THE SICULA OF MONOGRAPTUS SCANICUS TULLBERG}

SIR,- - I should like to add a note to the paper in the March-April number of this Magazine by Dr. Bulman on Monograptus scanicus Tullberg. I now have two individuals of this species showing the sicula and first theca, which were obtained, like Dr. Bulman's material, from a Lower Ludlow boulder from the Pleistocene of the North German Plain. These are now in the

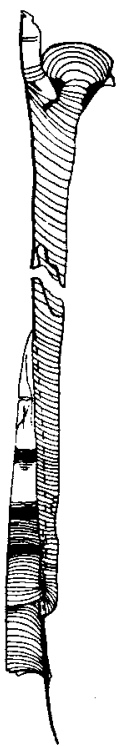

Monograptus scanicus Tullberg. The sicula and first theca. SM. A24341. $\times 30$ approx. Sedgwick Museum Collection, numbers SM. A24341 and 24342 .

The better preserved specimen is figured here. Growth lines can hardly be seen on the apical part of the sicula but in the apertural region and on the first theca they are in general well marked. The prosicula is probably that part above the first thickened band on the sicula, and there are three of these "stillstandsgürtel " on the metasicula.

The specimen is rather dark near the foramen, but the growth lines would seem to be as shown in the accompanying diagram. The initial bud arises from a foramen which is formed as a small notch in the margin of the metasicula and later closed by addition of further growth rings. The bud grows laterally and then upwards, the thecal tube widening gradually. The interthecal septum of the first theca is short and the apertural lappets are as described by Bulman, with the right one slightly larger and overlapping the left. This asymmetry (right lappet larger than left) is the same also in all other fragments examined.

The dimensions of the specimen are as follows:

length of sicula $1.15 \mathrm{~mm}$., with thickened bands beginning $0 \cdot 4,0 \cdot 6$, and $0.75 \mathrm{~mm}$. from the apex,

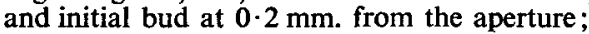
apertural diameter of sicula $0 \cdot 1 \mathrm{~mm}$.; length of first theca to ventral lip $1.75 \mathrm{~mm}$. and width just below interthecal septum $0.15 \mathrm{~mm}$. ; prothecal ratio (excluding apertural processes) 94 per cent.

The second specimen is almost exactly the same in dimensions and proportions.

Thus in all Monograpti of which the development is known, the foramen of the initial bud is formed by a notch (see the work of Kraft, Wiman, Cox). In addition $M$. scanicus may be closely compared with the species figured by Kraft, in the possession of thickening bands in the sicula. Neither of these features are yet known in genera other than Monograptus.

\section{SeDGWick Museum, CAMBRIDGE. 22nd April, 1953.}

MARgaret Walker. 